\title{
Influence of tempering conditions on microstructure and mechanical properties of a newly designed low alloy ultrahigh strength steel
}

\author{
Y.-Y. Feng, C. Xu, Y.-L. Sun, C.-C. Bu, Y.-D. Cao, G. Chen* \\ Engineering Research Center of Materials Behavior and Design, Ministry of Education, \\ Nanjing University of Science and Technology, Nanjing 210094, P. R. China
}

Received 17 January 2017, received in revised form 14 August 2017, accepted 15 August 2017

\begin{abstract}
In this research, we designed one low alloy ultrahigh strength steel and performed an analysis of the mechanical properties and microstructures at different tempering conditions. The structure of the steel is lath martensite with a high density of dislocations combined with many carbides precipitated in the microstructures at specific conditions. Strength and hardness of the material were found to decrease, while toughness varied differently as the tempering temperature increased. The best combination of strength and toughness was obtained when tempered at $200^{\circ} \mathrm{C}$. Prolonging the holding time led to higher strength but lowered toughness. Tempered martensite embrittlement occurred at $300-400^{\circ} \mathrm{C}$. The ruptured surface indicated that the material had fractured in a quasi-cleavage manner at $100{ }^{\circ} \mathrm{C}$, quasi-cleavage and microvoid coalescence fracture occurred at $200-400^{\circ} \mathrm{C}$, intergranular fracture at $500{ }^{\circ} \mathrm{C}$.
\end{abstract}

K e y w or d s: low alloy ultrahigh strength steel, tempering temperature, holding time, mechanical properties, microstructure

\section{Introduction}

Ultrahigh-strength steel [1-6] with the strength of more than $1400 \mathrm{MPa}$ and a minimum yield strength of $1245 \mathrm{MPa}$ is widely used in several high-technology applications, such as automobile, aerospace and water turbine in hydroelectric power station including pressure vessel, etc. [7]. New methods for improving mechanical properties have been studied for many years. $\mathrm{Cr}$ and Mo are always added to enhance hardenability. While the addition of $\mathrm{Cr}$ improves the corrosion resistance and stacking faults energy [8, 9], Mo addition can improve toughness and strength because Mo affects the transformation temperature [10]. Mn and $\mathrm{Ni}$ are added to enhance toughness owing to $\mathrm{Mn}$ and $\mathrm{Ni}$ can promote the formation of residual austenite. $\mathrm{Nb}$ is always used to refine the grain size and reduce the tempering brittleness $[11,12]$. $\mathrm{Mn}$ and $\mathrm{Cr}$ have been reported to provide higher resistance to softening.

Microstructures of ultrahigh strength steel are predominated by martensite, bainite, austenite, etc.
The transformation of austenite-martensite depends on martensite starting temperature (Ms), martensite finishing temperature (Mf), composition, austenite strength and the deformation rate [13]. As a transformation product, martensite plays a dominant role in determining the mechanical properties of structural steel. Martensite is used in tempering conditions $\left(200-300^{\circ} \mathrm{C}\right)$ rather than untempering conditions. After tempering, the brittle fracture of martensite steel is suppressed, and the desired combination of strength and ductility is obtained. A series of stages are involved in the tempering process. The first stage is the segregation and redistribution of carbon atoms which takes place in the lattice defects when the tempering temperature is in an average of $80-100^{\circ} \mathrm{C}$. The second stage is the retained austenite films decompose into ferrite and cementite when the tempering temperature increases from 200 to $300^{\circ} \mathrm{C}[14,15]$. The third stage is the transformation of carbides. For example, cementite was observed when the tempering temperature range was between 250 to $350^{\circ} \mathrm{C}$. When the tempera-

*Corresponding author: tel./fax: +86(025)84315159; e-mail address: gchen@njust.edu.cn 
Table 1. Chemical composition of the new low alloy ultrahigh strength steel (wt.\%)

\begin{tabular}{ccccccccccccc}
\hline Elements & $\mathrm{C}$ & $\mathrm{Si}$ & $\mathrm{Mn}$ & $\mathrm{Cr}$ & $\mathrm{Ni}$ & $\mathrm{Mo}$ & $\mathrm{Nb}$ & $\mathrm{Al}$ & $\mathrm{S}$ & $\mathrm{Fe}$ & $\mathrm{Bal}$ \\
\hline & 0.34 & 1.98 & 1.85 & 0.7 & 1.1 & 0.79 & 0.028 & 0.065 & 0.006 & $\mathrm{Bal}$ \\
\hline
\end{tabular}

ture is higher than $350^{\circ} \mathrm{C}$, the carbides coarsen. The martensite tempering process is influenced by tempering temperature, holding time, heating rate and the carbon content. When the content of added carbon is less than $0.2 \%$, the microstructure is plate martensite with a substructure of less dislocation. A mixed structure of plate martensite and lath martensite with substructures of dislocation and twin are observed in the microstructure by adding $0.2-1 \%$ carbon in the steel. Complicated structures form when more carbon content is added. Therefore, the mechanical properties of quenched and tempered steel strongly depend on its tempering conditions and carbon content.

The objective of this present study was to examine the tempered structures of the new steel produced under various tempering conditions, in addition, to evaluate the influence of tempering conditions on the mechanical properties and microstructures while avoiding the occurrence of the tempered martensite embrittlement.

\section{Materials and methods}

\subsection{Sample preparation}

Ingots used in our study were made by arc melting under Ar atmosphere and re-melting several times. The chemical composition of the new steel is shown in Table 1. Steel ingots were heated at $900{ }^{\circ} \mathrm{C}$ in air and then hot-forged to bar stocks with a diameter of $12 \mathrm{~mm} \times 8 \mathrm{~mm}$. To obtain different quenched and tempered martensite structures, the bar stocks were firstly heated at $920^{\circ} \mathrm{C}$ for $1 \mathrm{~h}$ in air and quenched in oil. The quenched bars were tempered at 100, 200, 300,400 , and $500{ }^{\circ} \mathrm{C}$ in air for $2 \mathrm{~h}$ and cooled in air. Meanwhile, bar stocks tempered at $200^{\circ} \mathrm{C}$ for $24 \mathrm{~h}$ (air cooled) are also discussed here to understand the function of holding time on the mechanical properties and microstructures.

\subsection{Mechanical tests}

Tensile specimens and Charpy-V impact specimens were obtained from the extruded bars after tempering process. A nominal gauge length of $30 \mathrm{~mm}$ with the diameter of $3 \mathrm{~mm}$ was utilized to measure the deformation of the specimens. To ensure the consistency, three specimens were used in every tensile test. The tensile tests were performed on CMT 5504 testing machine at room temperature in air with a strain rate of $1 \mathrm{~mm} / \mathrm{min}$. Ultimate tensile strength (UTS), yield strength (YS), elongation (El), and reduction in area (RA) were calculated. Charpy $2-\mathrm{mm} \mathrm{V}$ specimens with the size of $55 \mathrm{~mm} \times 10 \mathrm{~mm} \times 5 \mathrm{~mm}$ were tested at $-40{ }^{\circ} \mathrm{C}$ on an Instron machine to assess impact toughness. Rockwell-C hardness (HRC) tests were measured by a HR-150A Rockwell hardness tester to examine the variation of hardness under different tempering conditions. To obtain accurate HRC value, the average of over ten locations on the particular sample was calculated.

\subsection{Microstructure analysis}

Scanning electron microscopy (SEM) and transmission electron microscopy (TEM) were used to characterize the tempered microstructures. The specimens were etched in a $5 \%$ (by volume) nital solution. Tempered samples for TEM examination were cut by a spark cutting machine with a diameter of $3 \mathrm{~mm}$ and $1 \mathrm{~mm}$ thickness. The $1 \mathrm{~mm}$ thickness samples were mechanically ground to $50 \mu \mathrm{m}$ and electropolished in a $5 \%$ perchloric acid and $95 \%$ alcohol solution using a jet thinning instrument. During the process, both sides of the samples at the centre were jet thinned. FEI Tecnai 20 electron microscope was used to examine the thin foil specimens at a voltage of $200 \mathrm{kV}$ at room temperature to reveal the substructures and carbide precipitates. The observations of fractured surfaces obtained from impact tests were studied by SEM.

\section{Results}

\subsection{Mechanical properties}

Table 2 illustrates the mechanical properties of the new steel measured as a function of tempering conditions. As shown in Table 2, HRC values decrease quickly as tempering temperature increases from 100 to $500^{\circ} \mathrm{C}$. A platform is found in the $\mathrm{HRC}$ values when the tempering temperature is increased from 300 to $400^{\circ} \mathrm{C}$. The strength results shown in Table 2 indicate that the strength decreases as tempering temperatures increase. Sharp descents are found in the toughness when the temperature increases from 200 to $300^{\circ} \mathrm{C}$. This indicates that the toughness is very sensitive to the tempering temperature. The same results were found by Cao Yi [16] and Woei-Shyan Lee [17]. Woei-Shyan Lee suggested that the formation of carbide films is always responsible for the oc- 
Table 2. Mechanical properties of the new design steel at different tempering conditions

\begin{tabular}{lcccccc}
\hline Conditions $\left({ }^{\circ} \mathrm{C}\right) \times(\mathrm{h})$ & $100 \times 2$ & $200 \times 2$ & $300 \times 2$ & $400 \times 2$ & $500 \times 2$ & $200 \times 24$ \\
\hline UTS (MPa) & 2063 & 1990 & 1916 & 1765 & 1670 & 2144 \\
YS (MPa) & 1746 & 1693 & 1645 & 1492 & 1400 & 1805 \\
HRC & 53.6 & 52.8 & 51.8 & 51.7 & 49.2 & 56.1 \\
RA (\%) & 44 & 56 & 50 & 50 & 50 & 43 \\
El (\%) & 9.2 & 9.2 & 7.6 & 8.8 & 9.0 & 7.6 \\
Toughness $\left(\mathrm{J} \mathrm{cm}^{-2}\right)$ & 3 & 8 & 4.4 & 4 & 4.5 & 5 \\
\hline
\end{tabular}
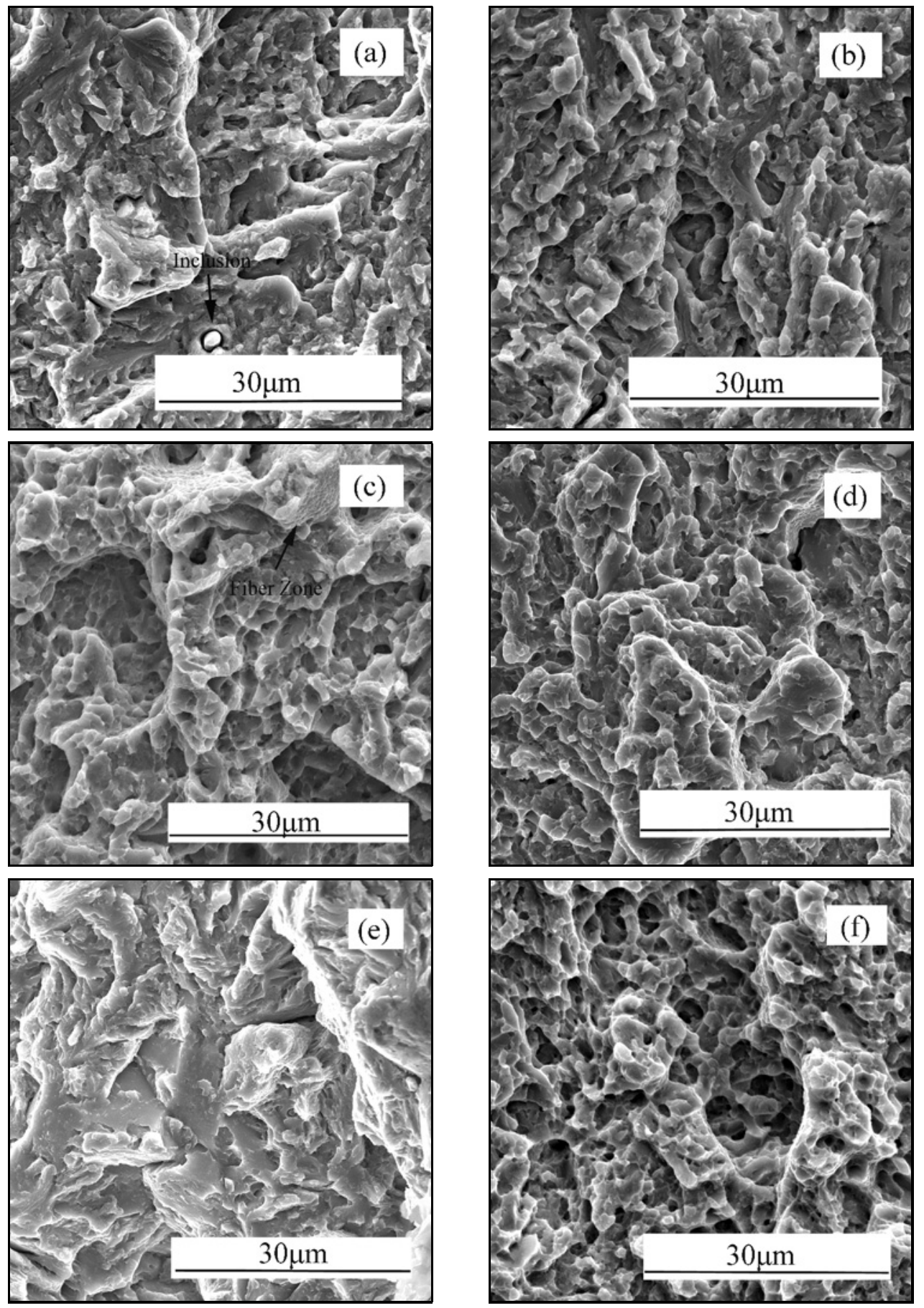

Fig. 1. Fracture surfaces of the steel tempered at (a) $100{ }^{\circ} \mathrm{C}$, (b) $200{ }^{\circ} \mathrm{C}$, (c) $300{ }^{\circ} \mathrm{C}$, (d) $400{ }^{\circ} \mathrm{C}$, (e) $500{ }^{\circ} \mathrm{C}$, and (f) $200{ }^{\circ} \mathrm{C}$ $\times 24 \mathrm{~h}$. 

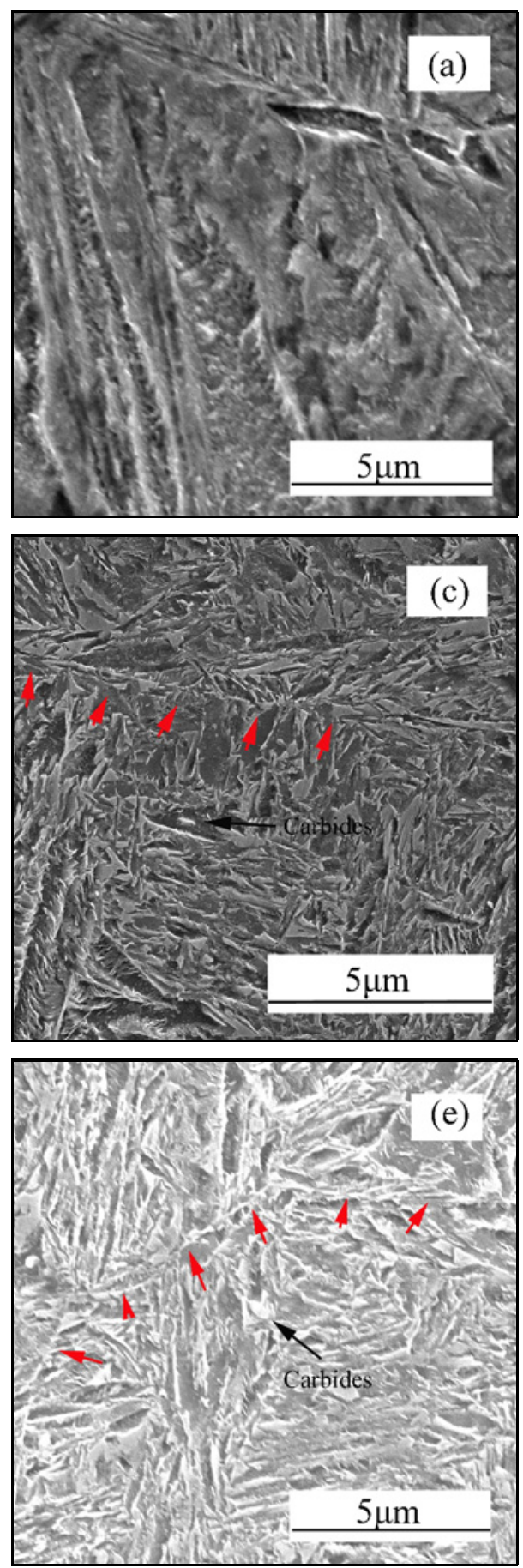
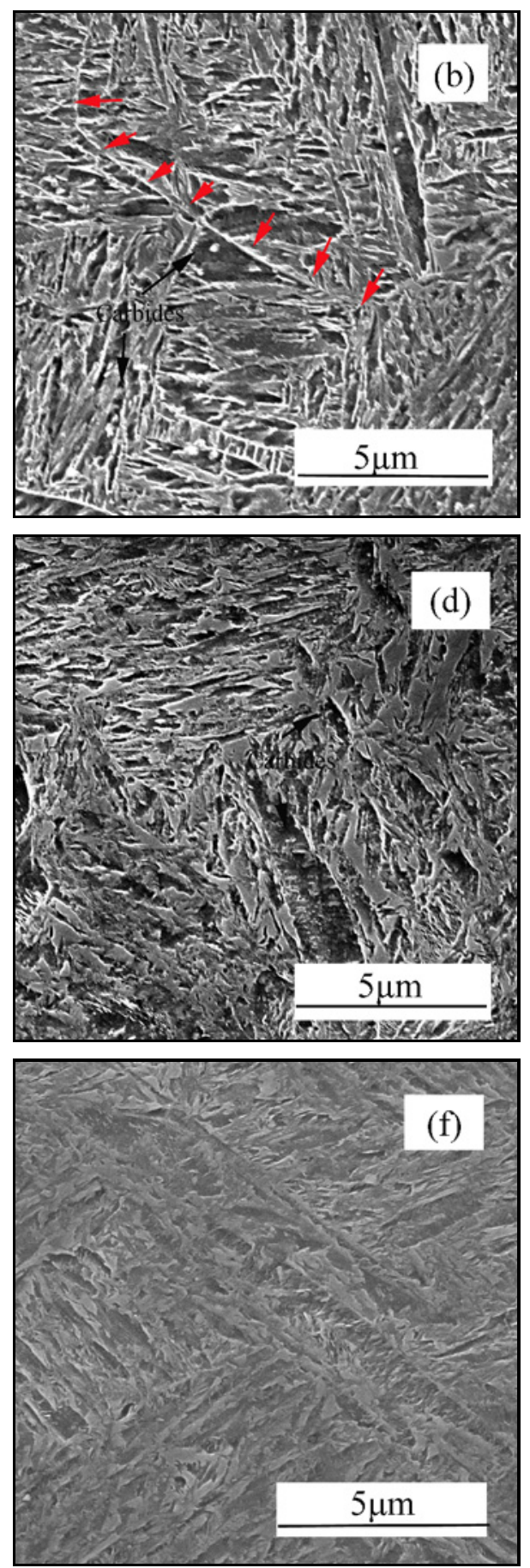

Fig. 2. SEM micrograph of steel tempered at (a) $100{ }^{\circ} \mathrm{C}$, (b) $200{ }^{\circ} \mathrm{C}$, (c) $300^{\circ} \mathrm{C}$, (d) $400{ }^{\circ} \mathrm{C}$, (e) $500^{\circ} \mathrm{C}$, and (f) $200^{\circ} \mathrm{C} \times 24 \mathrm{~h}$.

currence of temper embrittlement. In fact, the different heat treatment process and the thermal instability of inter-lath austenite after tempering lead to the formation of carbide films. The results listed in Table 2 show that the strength and HRC increased, but the toughness decreased as the holding time was prolonged. This is due to the increased distortion which occurred during the formation of plate martensite and the precipitation of carbides. The results at different tempering conditions indicate that tempering tempe- rature significantly influences the mechanical properties.

\subsection{Fractured surfaces}

The impact fractured surfaces obtained at various tempering conditions are shown in Fig. 1. The morphologies of the fractured surfaces revealed distinct differences in the underlying mechanism at selected conditions. Crack propagation occurs along the grain 
boundaries. The fracture mode of the material tempered at $100{ }^{\circ} \mathrm{C}$ is quasi-cleavage as shown in Fig. 1a. The cleavage occurs between the abundance of carbides at a very fine scale. Considering the temperature of $200^{\circ} \mathrm{C}$, more dimples can be found on the fractured surface indicating that the materials failed in a ductile fracture mode. Two regions can be distinguished from the fractured appearance of the steel tempered at $300^{\circ} \mathrm{C}$ as shown in Fig. 1c: one is "fibre region", and the other is micro-void coalescence. Comparing with Fig. 1b, the micro-voids are found to grow and coarsen with increasing tempering temperature. The effect of micro-void coalescence accelerates the fracture during the deformation process. The fracture mode changes from transgranular micro-void coalescence to intergranular fracture. As the tempering temperature is increased to $500^{\circ} \mathrm{C}$, the fracture mode is dominated by the intergranular fracture with no micro-void appearance on the fractured surface as shown in Fig. 1e, the material can be easily fractured. The fractured surface at $200^{\circ} \mathrm{C}$ for $24 \mathrm{~h}$ is composed of quasi-cleavage and dimples as listed in Fig. 1f. The coarsening voids led to a decline in the toughness compared to Fig. $1 \mathrm{~b}$.

\subsection{Microstructures}

Figure 2 represents the SEM micrographs of the material tempered at $100,200,300,400,500{ }^{\circ} \mathrm{C}$ for $2 \mathrm{~h}$ and $200^{\circ} \mathrm{C}$ for $24 \mathrm{~h}$, respectively. Full martensitic microstructures are obtained after quenching and tempering processes with austenite stability elements (Cr, Mo, Si, and $\mathrm{Nb}$ ) added in the steel. The sample tempered at $100^{\circ} \mathrm{C}$ presents as-quenched martensitic morphology. The grain size is large, and lots of spheroidized carbides (marked with black arrows) precipitate in the microstructure as shown in Fig. 2a [18]. The carbon atoms in the parent austenite become an interstitial solid solution in the new lattice after the transformation [19]. The morphology obtained at $200^{\circ} \mathrm{C}$ shows that the grain size becomes finer gradually as compared to that in Fig. 2a. The prior grain boundaries are marked with red arrows, and the carbides in the intra-lath are marked with black arrows. The progressive increment in temperature from 300 to $400{ }^{\circ} \mathrm{C}$ results in the transformation of microstructures. When the tempering temperature increased to $500^{\circ} \mathrm{C}$, the grain boundaries coarsened as shown in Fig. 2e. Figure 2f shows that with prolonged holding time, the martensitic laths become finer with more carbides precipitated in the intra-lath as compared to Fig. 2b.

Typical lath martensites (identified as body-centered cubic phase) having a high density of dislocations are represented in Fig. 3. Figure 3a shows extensive spherical-shaped carbides and high density of dislocations distributed uniformly in the martensitic lath. The carbide size is about $\sim 50 \mathrm{~nm}$ after tem- pering at $200^{\circ} \mathrm{C}$. By raising the tempering temperature to $300^{\circ} \mathrm{C}$, more of the $\varepsilon$-carbides precipitate along the boundaries as compared to $\eta$-carbide or $\eta$ - $\mathrm{Fe}_{2} \mathrm{C}$ [20]. Figure 3c shows the microstructure tempered at $400{ }^{\circ} \mathrm{C}$. Figure $3 \mathrm{~d}$ shows that spherical-shaped and needle-like carbides can be found in the microstructure. The observed carbides are coarser and randomly distributed. The intra-lath carbides maintain a specific orientation against the adjacent laths. Multivariate carbides exist at about $50^{\circ}$ to the lath boundaries. Compared to the critical carbides, intra-lath carbides with smaller size are generated owing to the final stage in the precipitation and dissolution of carbides. With an increase of tempering temperature to $500^{\circ} \mathrm{C}$, the lath gradually coarsens, and the density of dislocations decreases, while more carbides precipitate along the boundaries. The combined effect of the three factors leads to the reduction in strength and HRC. Comparing with Fig. 3a, more carbides and a higher density of dislocations are found in the structure as shown in Fig. 3f. The transformation of martensite under the tempering conditions leads to the formation of laths with a different thickness in the microstructure. The first one is coarsened martensitic lath with a low density of dislocation which is generated at the beginning of the martensite formation process at a higher temperature. The second one is fine martensitic lath with a high density of dislocations which was formed during the transformation of martensite. The thickness of coarsened martensite lath is more than $500 \mathrm{~nm}$ while the thickness of thin martensite lath is less than $100 \mathrm{~nm}$. The finer martensite lath with a higher density of dislocations and more carbide precipitates enhances the strength and hardness as shown in Fig. 3f rather than that in Fig. 3a.

\section{Discussion}

To understand the influence of tempering conditions on mechanical properties, the following mathematical relationships were used to evaluate the strength contributions in the martensite steel. The microstructure obtained from the tempering process exhibits lath martensite associated with a highly dislocated substructure $[18,21]$. Meanwhile, many carbides precipitate in the matrix. The strength of the low alloy ultrahigh strength martensite steel is calculated as [21]:

$$
\begin{aligned}
& \sigma=\sigma_{\mathrm{Fe}}+\sum \sigma_{\mathrm{SS}}+ \\
& \sigma_{\mathrm{C}}+\frac{115}{\bar{L}_{\mathrm{T}}}+7.34 \times 10^{-6} \sqrt{\rho_{\mathrm{D}}}+\frac{42}{\lambda_{\mathrm{p}}} \mathrm{MPa}
\end{aligned}
$$

where $\sigma_{\mathrm{Fe}}$ is the strength of pure annealed iron, $\sum \sigma_{\mathrm{SS}}$ is the effect of solid solution strengthening owing to 

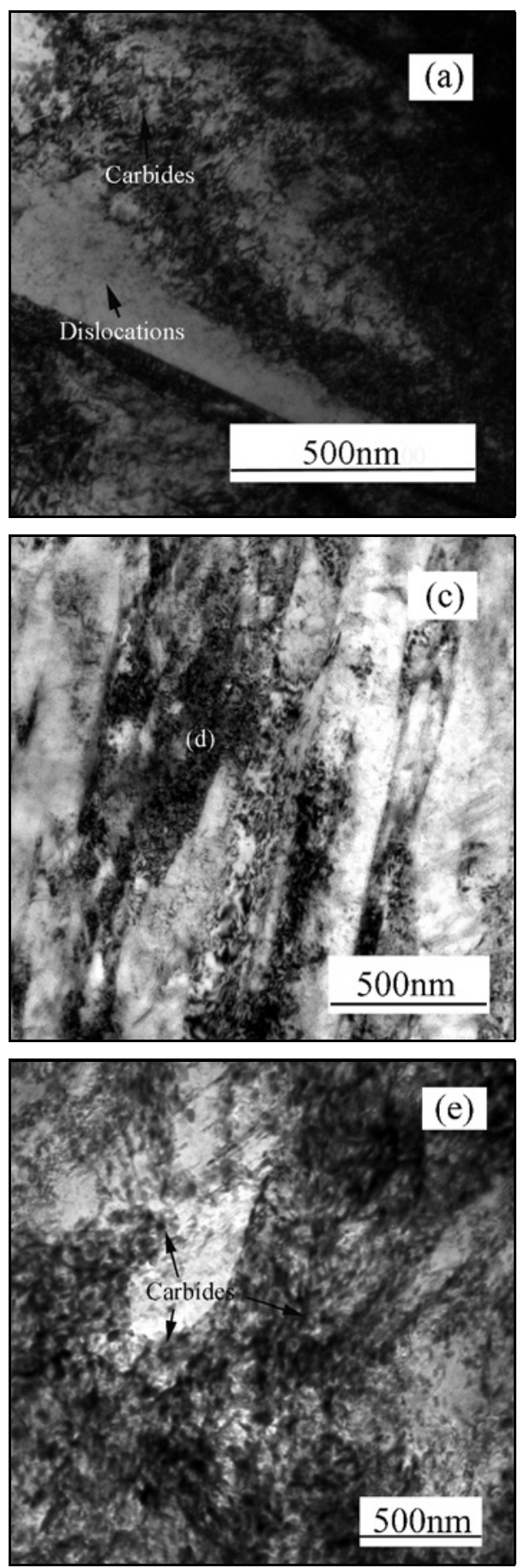

Fig. 3. TEM micrographs of the steel tempered at (a) $200{ }^{\circ} \mathrm{C}$, (b) $300^{\circ} \mathrm{C}$, (c) (d) $400{ }^{\circ} \mathrm{C}$, (e) $500{ }^{\circ} \mathrm{C}$, and (f) $200^{\circ} \mathrm{C} \times 24 \mathrm{~h}$.

the alloying elements, and $\sigma_{\mathrm{C}}$ is the carbon solid solution effect. $\sigma_{\mathrm{SS}}=84[\mathrm{Si}]+32[\mathrm{Mn}]+13[\mathrm{Mo}]-30[\mathrm{Cr}]$ $[22], \sigma_{\mathrm{C}}=1722.5 \sqrt{[\mathrm{C}]}[23]$, where the concentrations of the alloy elements are in wt. $\% ; \bar{L}_{\mathrm{T}}$ is the width of the martensite lath $(\mu \mathrm{m}), \rho_{\mathrm{D}}$ is the dislocation density, and $\lambda_{\mathrm{p}}$ is the distance between carbide particles.

A single chemical composition was used. Therefore, the carbon remained in the solid solution after tempering can be ignored in this study. Only the dis-
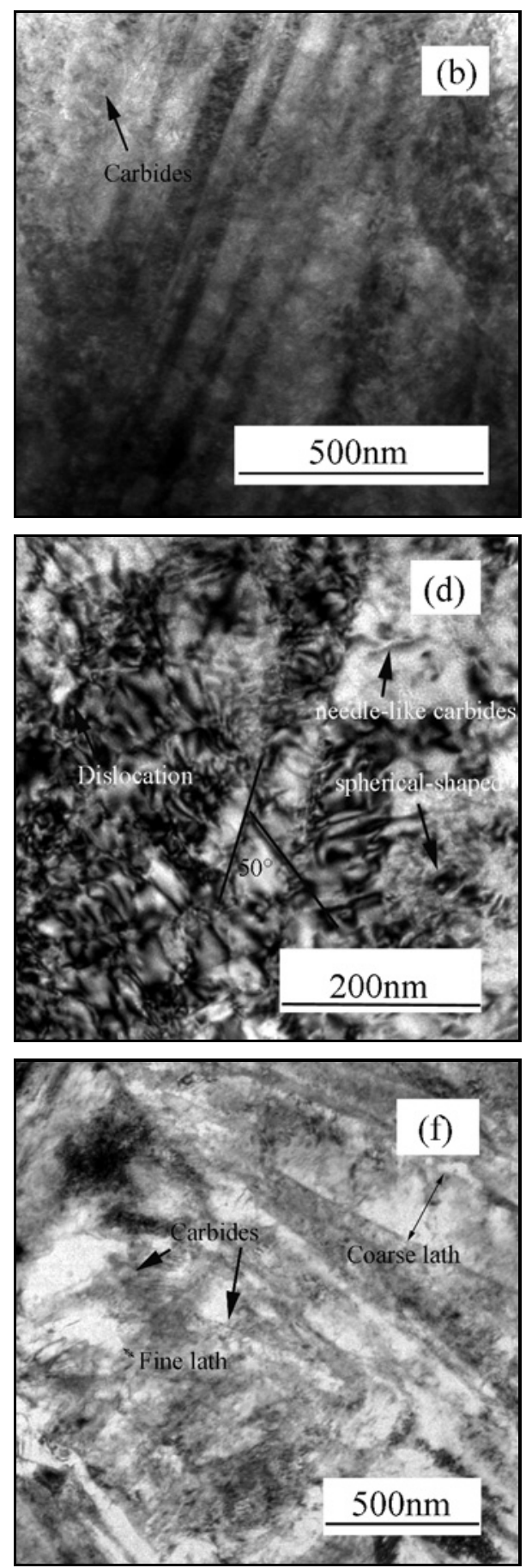

location density and precipitation strengthening were evaluated for the contribution towards the strength.

The particle strengthening $\left(\sigma_{\mathrm{p}}\right)$ can be calculated as:

$$
\sigma_{\mathrm{p}}=\frac{0.627 G b f_{\mathrm{v}}^{1 / 2}}{d} \ln \frac{d}{2 b},
$$

where $d$ is the diameter of carbides, $f_{\mathrm{v}}$ is the volume fraction of carbides, $G$ is the shear modulus of the matrix $\left(8.026 \times 10^{4} \mathrm{MPa}\right)$, and $b$ is $0.248 \mathrm{~nm}$. 
The particle diameter and the volume fraction of carbides are estimated from the high-resolution FE-SEM and TEM micrographs using the formula described in [24].

Figure $3 \mathrm{~b}$ indicates that the amount of $\varepsilon$-carbide decreases when the tempering temperature increases to $300^{\circ} \mathrm{C}$. Meanwhile, cementite starts to form as a result of increased activity of supersaturated carbon in the lath matrix. $\varepsilon$-carbide is gradually replaced by the nucleation of cementite [25] leading to a diminished strengthening effect. Moreover, the transformation of carbides from retained austenite and impurities is responsible for the occurrence of tempering embrittlement $[9,26-28]$ when the tempering temperature is increased from 300 to $400^{\circ} \mathrm{C}$. As a consequence of increasing the tempering temperature over $400^{\circ} \mathrm{C}$, the reaction between carbides affects the mechanical properties. The carbides precipitated in the martensitic structure influence the size of dimples. With prolonged holding time as shown in Fig. 3f, more carbide can be found in the martensite structure which enhances the strength of the materials as compared to that tempered at $200^{\circ} \mathrm{C}$ for $2 \mathrm{~h}$. The precipitation of fine $\varepsilon$-carbide in the martensite lath improves its toughness. However, the strength and HRC decrease because of the softened structure owing to the dissolution of carbon during the tempering process. The results indicate that increased tempering temperature leads to decreased solid solution strengthening because of the dissolution of carbon atoms and the precipitation of carbides during the tempering process.

The dislocations contributions to strength are estimated as:

$$
\sigma_{\rho}=7.34 \times 10^{-6} \sqrt{\rho_{\mathrm{D}}} .
$$

L. Malik and J. A. Lund [29] pointed out that the dislocations play very important role in the strengthening mechanisms. They suggested that the density of dislocations in the martensite lath decreased with increasing tempering temperature. Cox [30] discovered a marked decline in the density of dislocations in the martensite lath with increased tempering temperature while no noticeable increase in the size of martensite lath. Speich and Swann [31] proposed a different strengthening technique defined as "increased dislocation density plus martensite/martensite boundaries and the cell walls or internal twins within the transformed region". The decline in the density of dislocations leads to reduced hardness and strength.

Therefore, the carbide dispersion and dislocated substructure in the tempered steel are reasonable for the variation of mechanical properties under different tempering conditions.

\section{Conclusions}

A systematic study on the influence of tempering conditions on the microstructures and mechanical properties of the newly designed low alloy ultrahigh strength steel has been performed in this paper. Based on the presented results, three important findings are listed below:

1. As the tempering temperature increases from 100 to $500^{\circ} \mathrm{C}$, UTS, YS and HRC decrease. A sharp decline is observed in toughness when the tempering temperature increases from 200 to $300^{\circ} \mathrm{C}$. UTS, YS and $\mathrm{HRC}$ increase while the toughness decreases as the holding time is prolonged.

2. Fractured surfaces obtained from impact tests at $-40^{\circ} \mathrm{C}$ indicate that the fracture mode is mainly quasi-cleavage at lower tempering temperature. As the tempering temperature increased from 200 to $300^{\circ} \mathrm{C}$, the fractured mode is dominated by quasi-cleavage and dimpled fracture. The fractured mode is intergranular when tempered at $500^{\circ} \mathrm{C}$. As holding time is prolonged, more dimples can be found on the quasicleavage surface.

3. TEM observation shows that the carbide dispersion and dislocation substructure in the tempered steel mainly influence mechanical properties.

\section{Acknowledgements}

Foundation Item: Item sponsored by the National Natural Sciences Foundation of China (No. 51571117), the Cooperative Innovation Fund of Jiangsu Province (No. BY2015004-10).

\section{References}

[1] Zhou, S., Zhang, K., Wang, Y., Gu, J. F., Rong, Y. H.: Mater. Sci. Eng. A, 528, 2011, p. 8006. doi:10.1016/j.msea.2011.07.008

[2] Feng, Y. Y., Xu, C., Bu, C. C., Su, X., Pan, X., Cao, Y. D., Chen, C.: Advances in Mater. Proc. Technol., 3, 2017, p. 616. doi:10.1080/2374068X.2017.1350548

[3] Misra, R. D. K., Jia, Z., O'Malley, R., Jansto, S. J.: Mater. Sci. Eng. A, 528, 2011, p. 8772. doi:10.1016/j.msea.2011.08.047

[4] Lee, B. S., Kim, M. C., Yoon, J. H., Hong, J. H.: Int. J. Press. Vess. Pip., 87, 2010, p. 74. doi:10.1016/j.ijpvp.2009.11.001

[5] Michael, M. D., David, S. N.: Acta Mater., 59, 2011, p. 1881. doi:10.1016/j.actamat.2010.11.054

[6] Rao, M. P., Sarma, V. S., Sankaran, S.: Mater. Sci. Eng. A, 568, 2013, p. 171. doi:10.1016/j.msea.2012.12.084

[7] Ki, L. H., Sang, P. G., Min, K. C., Bong, L. S., Dang, W. M.: Mater. Sci. Eng. A, 529, 2011, p. 156. doi:10.1016/j.msea.2011.09.012

[8] Li, S. F., Zhou, Z. J., Jang, J. S., Wang, M., Hu, H. L., Sun, H. Y., Zou, L., Zhang, G. M., 
Zhang, W.: J. Nucl. Mater., 455, 2014, p. 194. doi:10.1016/i.jnucmat.2014.05.061

[9] Kim, J. K., Kim, Y. H., Kim, K. Y.: Scripta Mater., 63, 2010, p. 449. doi:10.1016/i.scriptamat.2010.05.002

[10] Chen, X. W., Qiao, G. Y., Han, X. L., Wang, X., Xiao, F. R., Liao, B.: Mater. Des., 53, 2014, p. 888. doi:10.1016/i.matdes.2013.07.037

[11] Wang, Y. W., Feng, C., Xu, F. Y.: ISIJ Int., 17, 2010, p. 49. doi:10.13228/i.boyuan.issn1006-706x.2010.01.014

[12] Hausmann, K., Krizan, D., Spiradek, K. H., Pichler, A., Werner, E.: Mater. Sci. Eng. A, 588, 2013, p. 142. doi:10.1016/j.msea.2013.08.023

[13] Asadabad, M. A., Kheirandish, S., Novinrooz, A. J.: Mater. Sci. Eng. A, 527, 2010, p. 1612. doi:10.1016/j.msea.2009.10.042

[14] Thomson, R. C., Miller, M. K.: Acta Mater., 46, 1998, p. 2203. doi:10.1016/S1359-6454(97)00420-5

[15] Jung, M., Lee, S. J., Lee, Y. K.: Metall. Mater. Trans. A, 40, 2009, p. 551. doi:10.1007/s11661-008-9756-2

[16] Cao, Y., Wang, Z. D., Kang J., Wu, D., Wang, G. D.: ISIJ Int., 20, 2013, p. 70. doi:10.1016/S1006-706X(13)60085-0

[17] Lee, W. S., Su, T. T.: J. Mater. Proc. Technol., 87, 1999, p. 1986. doi:10.1016/S0924-0136(98)00351-3

[18] Qin, B., Wang, Z. Y., Sun, Q. S.: Mater. Charact., 59, 2008, p. 1096. doi:10.1016/j.matchar.2007.08.025

[19] Hutchinson, B., Hagstrom, J., Karlsson, O., Lindell, D., Tornberg, M., Lindberg, F., Thuvander, M.: Acta Mater., 59, 2011, p. 5845. doi:10.1016/j.actamat.2011.05.061
[20] Hirotsu, Y., Nagakura, S.: Acta Metall., 20, 1972, p. 645. doi:10.1016/0001-6160(72)90020-X

[21] Krauss, G.: Mater. Sci. Eng. A, 273-275, 1999, p. 40. doi:10.1016/S0921-5093(99)00288-9

[22] Young, C. H., Bhadeshia, H. K. D. H.: Mater. Sci. Technol., 10, 1994, p. 209. doi:10.1179/mst.1994.10.3.209

[23] Daigne, J., Guttmann, M., Naylor, J. P.: Mater. Sci. Eng. A, 56, 1982, p. 1. doi:10.1016/0025-5416(82)90176-8

[24] Hasan, H. S., Peet, M. J., Avettand-Fånoël, M. N., Bhadeshia, H. K. D. H.: Mater. Sci. Eng. A, 615, 2014, p. 340. doi:10.1016/j.msea.2014.07.097

[25] Nam, W. J., Lee, C. S., Ban, D. Y.: Mater. Sci. Eng. A, 289, 2000, p. 8. doi:10.1016/S0921-5093(00)00928-X

[26] Shiue, R. K., Lan, K. C., Chen, C.: Mater. Sci. Eng. A, 287, 2000, p. 10. doi:10.1016/S0921-5093(00)00831-5

[27] Maropoulos, S., Ridley, N., Kechagias, J., Karagiannis, S.: Eng. Fract. Mech., 71, 2004, p. 1695. doi:10.1016/j.engfracmech.2003.08.006

[28] Lis, A. K.: J. Mater. Proc. Tech., 106, 2000, p. 212. doi:10.1016/S0924-0136(00)00616-6

[29] Malik, L., Lund, J. A.: Metall. Trans., 6, 1972, p. 1403.

[30] Cox, A. R.: Suppl. Jap. Inst. Metall., 9, 1968, p. 118.

[31] Speich, G. R., Swann, P. R.: JIS Inst., 203, 1965, p. 480 . 